\title{
Inception, Growth and Decay of the Laurentide Ice Sheet
}

\section{by John T. Andrews and Robert J. Fulton}

The link between the Antarctic ice sheet and global sea levels is of immense importance to society, as concern grows about a possible worldwide rise of the oceans. One approach to this problem is to study the ice sheet that covered much of North America during the last glacial period. The authors review here some aspects of the birth, growth and disintegration of the Laurentide Sheet. (Ed.)

\section{The Laurentide Ice Sheet}

The ice mass that covered much of Canada and parts of the U.S.A. east of the Rocky Mountains during the Wisconsin Glaciation is termed the Laurentide Ice Sheet (Prest, 1969, 1984; Paterson, 1972). At its maximum this massive ice sheet (Fig. 1) covered an area comparable to that of the present Antaretic Ice Sheet, or approximately 12.6 million $\mathrm{km}^{2}$ (ef. Denton and Hughes, 1981a). The upper limit of thickness of this ice sheet can only be deduced, but all estimates fall in the range of 2 to $4 \mathrm{~km}$, depending on which set of assumptions are held. Thus, at its maximum the ice sheet presented a substantial barrier to airflow which, combined with the high albedo and surface slopes, meant that the ice sheet substantially modified the climate by its "mere" presence (e.g. Manabe and Broccoli, 1985; kutzbach and Wright, 1985).

Other globally important responses to the presence of this large ice sheet included the isostatic adjustment of the earth to this addition of Imass, i.e. glacial isostasy (e.g. Peltier and Andrews, 1983), and the effect on sea level of the conversion of ocean water into ice and snow. However, even after a century of research there is still a great deal of discussion concerning the growth and disintegration of this ice sheet.

Inception (When, Where and How?)

In a global sense, the $\delta 180$ record of foraminifera indicates that inception of the Laurentide Ice Sheet occurred during marine isotope stage 5 , notably substages $5 \mathrm{~b}$ and $5 \mathrm{~d}$. It is more difficult to attach a specific locality to this, but it would have occurred first at high latitudes and within the interval between 120,000 and 80,000 years ago (Budd and Smith, 1981; Williams, 1979). In Canada the Quaternary community has elected to define the Wisconsinan Stage, a chronostratigraphic term, as being included within marine isotope stages

Figure 1: Presumed flow patterns of the three main domes of the Laurentide Ice sheet about 18,000 years ago.
4, 3 and 2 (fulton, 1984). However, the Wisconsin Glaciation as an event, or series of events, probably extencled from around 110,000 to about 5,000 years ago.

One view of the location of the initial ice sheet is that it developed over the high plateaux of eastern North $\Delta$ merica and, possibly, keewatin (Ives et il., 1975; Williams, 1979) through the lowering of snowline. A second opinion is that there was in situ development of the ice sheet over the interior seas of Hudson bay and Foxe Basin through the mechanism of "freezing in" (Denton et al., 1986). Both processes are considered rapid, but what is in question is the climate during the inception phase. In the "freeze-in" model, the climate must have been extremely cold and arid, whereas advocates of the alternative hypothesis propose that the initial formation of the ice sheet was associated with "warm" conditions and stress the importance of increased snowtall (Aksu, 1985; Aksu and Mudie, 1985). However, both models may be required to explain different facets of the inception process (Andrews et al., 1986).

Growth

A major problem with the evaluation of the field data prior to about $40,000 \mathrm{yBP}$ lies in obtaining a reliable radiometric chronology. Although the history of the ice sheet is often divided into an early and late phase of growth with a middle period of interstadial conditions (e.g. Dreimanis and

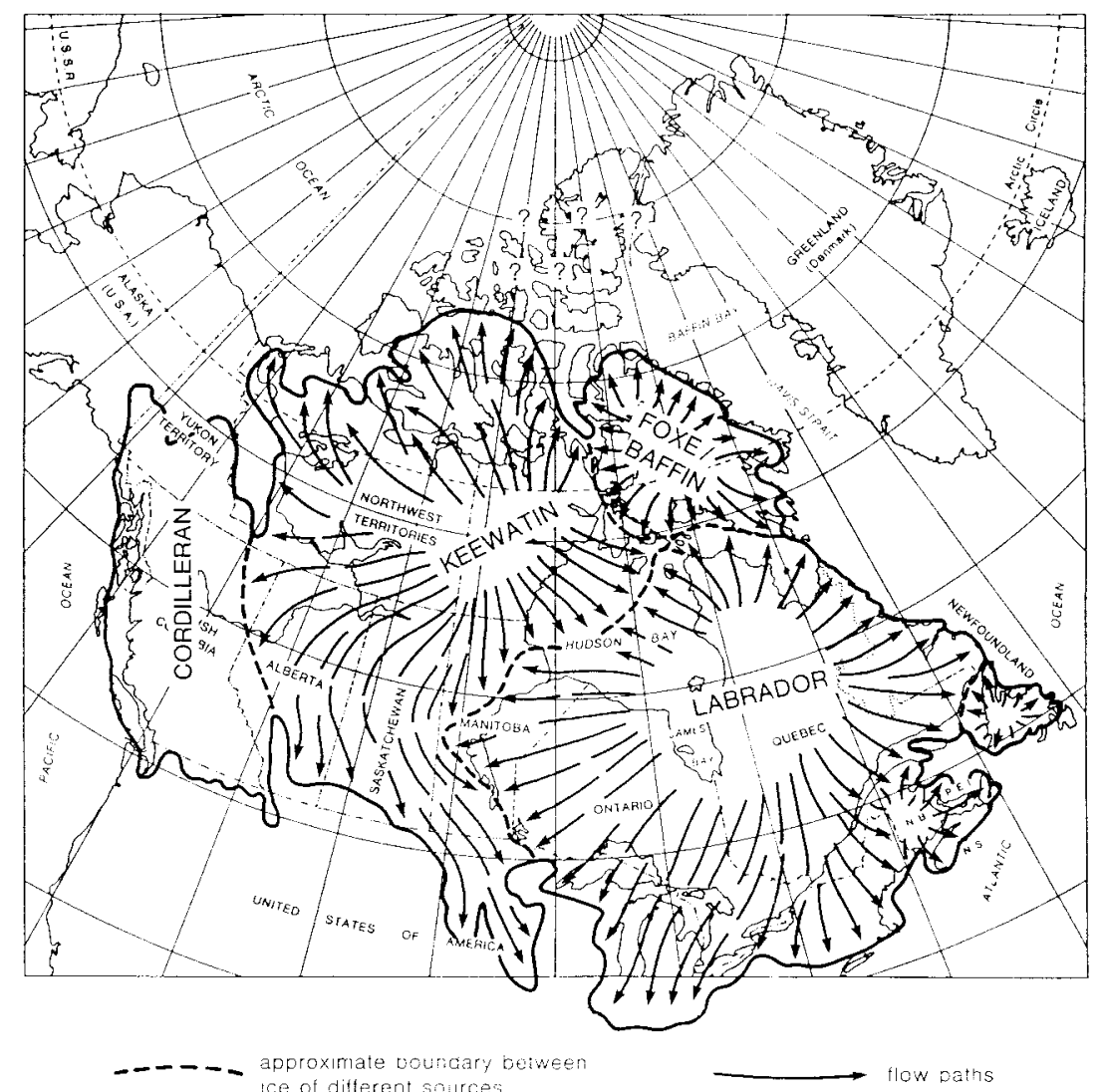


Goldthwait, 1973), it is very difficult to be absolutely sure of regional correlations during the middle and early periods. Current work (e.g. Clark and Lea, 1986) suggests that the early wisconsin Glaciation was most extensive in the northern and eastern sectors of the ice sheet whereas the southern margin expanded to its maximum during the Late Wisconsinan, about 18,000 years ago (Fulton, 1984). Uf considerable significance at the continental and global scales is whether the ice sheet remained essentially intact during marine isotope stages 4,3 and 2 , or whether substantial recession and even collapse of large areas of the ice sheet occurred (Budd and Smith, 1981; Fulton, 1984; Andrews et al., 1983; Shilts, 1985).

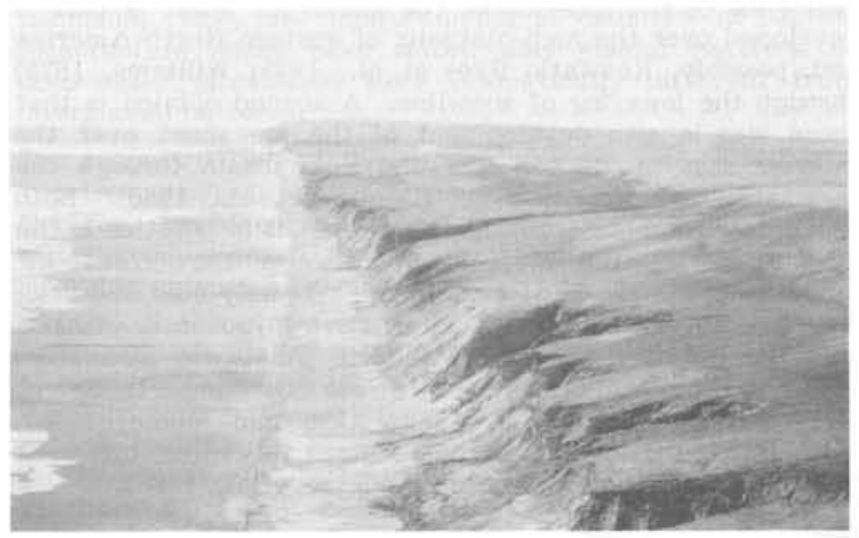

Figure 2: The southwest coast of Banks Island in the Canadian Arctic where tills and sediments from three glacial-interglacial cycles are exposed, of which the youngest is regarded as Early Wisconsinan. Photo by J-S. Vincent.

\section{Disintegration}

Hundreds of radiocarbon dates on peats, wood, and shell are now available and have been used to produce isochrones on the final deglaciation less than 18,000 yBP (Prest, 1969; Bryson et al., 1969). The southern margin reached its maximum extent between about 22,000 and 14,000 yBP at different localities (Mickelson et al., 1983; Fulton, 1984), but the northern margin apparently did not begin significant retreat until between 12,000 and 8,000 years ago (Dyke and Dredge, in press; Andrews, 1982).

Large areas of the Laurentide Ice Sheet lay below sea level and were linked to the North Atlantic via major troughs, such as the St. Lawrence Valley and Hudson Strait. There is considerable uncertainty about the geometry and thickness of the ice sheet around 18,000 years ago (e.g. Denton and Hughes, 1981a and b; Dyke et al., 1982; Boulton et al., 1985; Fisher et al., 1985; Peltier and Andrews, 1983). Of major concern is whether the ice sheet ever had a single dome lying over Hudson Bay, or whether the ice sheet always consisted of terrestrial-based ice divides (Fig. 1).

If the former proposition is correct then the ice sheet was marine based and the West Antarctic Ice Sheet of today is an appropriate analog for considering the mechanies of ice sheet collapse. These would include rapid calving and downdraw of the ice into the North Atlantic (e.g. Ruddiman and McIntyre, 1981), possibly associated with ice streams flowing over deformable beds, such as those proposed for the current West Antarctic Ice Sheet (Blankenship et al., 1986). If on the other hand, the ice sheet did not have a central dome over Hudson Bay, the terrestrial-based divides would have migrated little during deglaciation and the pattern of flow would have remained relatively constant until final stages of ice disintegration.

\section{Correlations Between Land and Sea}

The eastern margin of the ice sheet reached tidewater along much of its length. Deep-sea cores have begun to provide a picture of conditions in Baffin Bay and the Labrador Sea over the last Interglacial/Glacial cycle (Aksu, 1985; Aksu and Mudie, 1985), and initial attempts have been made to directly link the terrestrial and ocean records (Andrews et al., 1986). A key area in these matters is the intermediate area of shelf and fjords that link the terrestrial and deep-sea areas (e.g. Fig. 2). Research in such areas is rapidly adding to our knowledge of Late Wisconsinan glacial and nonglacial events (e.g. Scott et al., 1984; Praeg et al., 1986; Josenhans et al., 1986; Andrews et al., in press).

\section{Applications to Current Global Issues}

There is much concern today over the possible effects of a $\mathrm{CO}_{2}$-induced warming on the mass balance and stability of both the Greenland and Antaretic ice sheets (U.S. Department of Energy, 1985). In particular, a large portion of the West Antaretic Ice Sheet is grounded below present sea level and is thus potentially sensitive to changes in regional climate and oceans (Denton and Hughes, 1981a, 1983).

The West Antarctic Ice Sheet can be compared with the Laurentide Ice Sheet during the late Quaternary when the latter also had extensive areas grounded below sea level (i.e. Hudson Bay, Foxe Basin, and areas along the Aretic mainland coast and adjacent channels). What can be deduced from the mapped and dated history of deglaciation that is applicable to the West Antaretic Ice Sheet? Evidence from Hudson Strait and Hudson Bay (Andrews and Falconer, 1969; Gray and Lauriol, 1985; Andrews et al., in press) suggests that this marine-based section of the Laurentide Ice Sheet suffered two intervals of rapid calving and massive ice discharge. The first event occurred around 10,000 years ago and the second 2,000 years later. In both instances the rate of retreat of the ice front must have been measured in kilometers per year! Coincident with this final interval of ice sheet collapse there was a notable episode of relative sea level rise in NW Europe during the Littorina transgression.

It is the link between ice sheet history and global sea level variations that is of immediate concern to society. The melting of small valley glaciers and ice caps today is resulting in a rise of sea level of between 0.2 and 0.8 $\mathrm{mm} / \mathrm{yr}$. Even this small rise is eausing significant coastal erosion is many parts of the world.

If significant collapse of West Antaretica did take place, the impact would have been enormous. However, predictions of the mass balance have to weigh the offsetting effects of warming causing increased ablation versus warming that causes increased snowfall by enhancing the transfer of water vapour to the atmosphere. This dichotomy also appears in the history of the northeastern section of the Laurentide Ice Sheet, which became more active between 10,000 and 8,000 years ago (e.g. Andrews, 1982; Dyke and Dredge, in press ). This was a time when temperatures were rising but which was counterbalanced for at least 2,000 years by an increase in snow accumulation. In a real sense then, an understanding of the Laurentide Ice Sheet may allow predictions to be developed on the future dynamies of other ice masses.

INQUA 187. Symposium A: Inception, Growth and Decay of the Laurentide Ice Sheet. Organizers: R.J. Fulton (Canada) and J.T. Andrews (U.S.A.). 
Dr. J.T. Andrews is a Professor of Geological Sciences at the University of Colorado, and a member of the Institute of Aretic and Alpine Research (Boulder, Colorado 80302 , U.S.A.), where he moved after a 7-year stint with the Canadian Government. His major research interests are glacial and marine geology, especially in the Aretic.

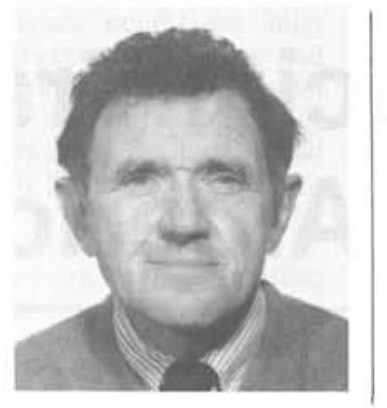

Dr. R.J. Fulton is with the Quaternary Geology Subdivision of the Terrain Seiences Division of the Geological Survey of Canada, (601 Booth Street, Ottawa, Ontario, Canada K1A 0E8). His prime research interests are Quaternary stratigraphy and sedimentation and the regional Quaternary geology of Canada.

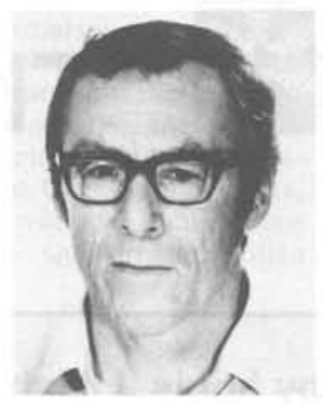

\section{References}

Aksu, A.E., 1985. Climatic and oceanographic changes over the past 400,000 years: evidence from deep-sea cores on Baffin Bay and Davis Strait. In: Andrews, J.T. (ed.), Quaternary Environments: Eastern Canadian Arctic, Baffin Bay, and Western Greenland. Allen and Unwin, Boston, p. 181-209.

Aksu, A.E. and Mudie, P.J., 1985. Late Quaternary stratigraphy and paleoecology of northwest Labrador Sea. Marine Micropaleontology, v. 9, no. 6, p. 537-557.

Andrews, J.T., 1982. Holocene glacier variations in the Eastern Canadian Aretic, A Review. Striae, v. 18, p. 9-14.

Andrews, J.T. and Falconer, G., 1969. Late glacial and postglacial history and emergence of the Ottawa Islands, Hudson Bay, North West Territories: Evidence on the deglaciation of Hudson Bay. Canadian Journal of Earth Sciences, v. 6, no. 4, p. 1263-1276.

Andrews, J.T., Aksu, A.E., Kelly, M., Klassen, K., Miller, G.H., Mode, W.N. and Mudie, P.J., 1986. Land/ocean correlations during the Last Interglacial/Glacial transition, Baffin Bay, Northwestern North Atlantic: A review. Quaternary Science Reviews, 4 (1985), p. 333-355

Andrews, J.T., Matthews, K.K., Osterman, L.E., Miller, G.H., HillzireMarcel, C. and Williams, K.M., in press. Deglaciation and meltwater events in Hudson Strait and the Eastern Canadian Arctic. Geo-Marine Letters.

Andrews, J.T., Shilts, W.W. and Miller, G.H., 1983. Multiple deglaciations of the Hudson Bay Lowlands, Canada, since deposition of the Missinaibi (Last-Interglacial) Formation. Quaternary Kesearch, v. 19, no. 1, p. 18-37.

Blankenship, D.D., Rooney, S.T., Alley, R.B. and Bentley, C.K., 1986. Seismic evidence for a deforming and eroding till beneath an active Antaretic ice stream (Abstract). EOS, v. 67, no. 44, p. 946.

Boulton, G.S. and Jones, A.S., 1979. Stability of temperate ice caps and ice sheets resting on beds of deformable sediment. Journal of glaciology, v. 24 , no. 90 , p. 29-43.

Boulton, G.S., Smith, G.D., Jones, A.S, and Newsome, J., 1985. Glacial geology and glaciology of the last mid-latitude ice sheets. Journal Geological Society of London, v. 142, no. 3, p. 447-474.

Bryson, R.A., Wendland, W.M., Ives, J.D. and Andrews, J.T., 1969. Radiocarbon isochrones on the disintegration of the Laurentide Ice Sheet. Arctic and Alpine Research, v. 1, no. 1, p. 1-14.

Budd, W.F. and Smith, I.N., 1981. The growth and retreat of ice sheets in response to orbital radiation changes. In: Sea level, Ice and Climatic Change. International Association of Hydrological Sciences, Publication no. 131 , p. $369-409$.

Clark, P.U. and Lea, P.D., 1986. Reappraisal of Early Wisconsin Glaciation in North America. Geological Society of America, Program with Abstracts, v. 18 , p. 565

Denton, G.H. and Hughes, T.J. (eds.), 1981a. The Last Great Ice Sheets. John Wiley, New York, 484p.

Denton, G.H. and Hughes, T.J. 1981b. The Arctic ice sheet: An outrageous hypothesis. In: Denton, G.H. and Hughes, T.J. (eds.), The Last Great Ice Sheets. John Wiley and Sons, New York, p. 437-467.

Denton, G.H. and Hughes, T.J., 1983. Milankoviteh theory of Ice Ages: Hypothesis of ice-sheet linkage between regional insolation and global climate. Quaternary Researeh, v. 20, no. 2, p. 125-144.

Denton, G.H., Hughes, T.J. and Karlen, W., 1986. Global ice-sheet system interlocked by sea level. Quaternary kesearch, v. 26, no. 1, p. 3-26.

Dreimanis, A. and Goldthwait, R.P., 1973. Wisconsin Glaciation in the Huron, Erie, and Ontario lobes. In: The Wisconsinan Stage. Geologieal Society of America Memoir no. 136, p. 71-106.

Dyke, A.S. and Dredge, L.A., in press. Quaternary Geology of the northwestern Canadian Shield. In: Fulton, R.J. Heginbottom, J.A. and Funder, S. (eds.), The Quaternary Geology of Canada and Greenland. Geological Survey of Canada, Geology of Canada, no. 1 .
Dyke, A.S., Dredge, L.A. and Vincent, J-S., 1982. Configuration and dynamies of the Laurentide Ice Sheet during the Late Wisconsin maximum. Geographie Physique et Quaternaire, v. 36, no. 1-2, p, 5-14.

Fisher, D.A., Reeh, N. and Langley, K., 1985. Objective reconstructions of the Late Wisconsinan Laurentide Ice Sheet and the significance of deformable beds. Géographie physique et Quaternaire, v. 39, no. 3, p. 229-238.

Fulton, R.J. (ed.), 1984. Quaternary Stratigraphy of Canada - A Canadian contribution to IGCP Project 24. Geological survey of Canada Paper 84-10, $210 \mathrm{p}$.

Gray, J.T. and Lauriol, B., 1985. Dynamies of the Late Wisconsin Ice Sheet in the Ungava Peninsula, interpreted from geomorphological evidence. Arctic and Alpine Research, v. 17, no. 3, p. 289-310.

Ives, J.D., Barry, R.G. and Andrews, J.T., 1975. Growth and decay of Laurentide Ice Sheet and comparisons with Fenno-Seandinavia. Naturwissenschaften, v. 62 , no. 3 , p. 118-125.

Josenhans, H.W., Zevenhuizen, J. and Klassen, R.A., 1986. Quaternary geology of the Labrador Shelf. Canadian Journal Earth Sciences, v. 23, p. $1190-1214$.

Kutzbach, J.E. and Wright, H.E., Jr., 1985. Simulation of the climate of 18,000 years BP: Results for the North American/North Atlantic/European sector and comparison with the geologic record of North America. Quaternary Science Reviews, v. 4, no. 3, p. 147-188.

Manabe, S. and Broceoli, A.J., 1985. A comparison of elimate model sensitivity with data from the last glacial maximum. Journal of Atmospheric Science, v. 42, p. 2643-2651.

Mickelson, D.iv., Clayton, L., Fullerton, U.S. and Borns, H.W., Jr., 1983. The Late Wisconsin glacial reeord in the United States. In: Porter, S.C. and Wright, H.E. Jr., (eds.), Late Quaternary Environments of the United States. Volume 1. The Late Pleistocene. University of Minnesota Press, Minneapolis, p. 3-37.

Paterson, W.S.B., 1972. Laurentide Ice Sheet: estimated volumes during the Late Wisconsin. Review of Geophysies and Space Physies, v. 10, no. 4, p. 885-917.

Peltier, W.R. and Andrews, J.T., 1983. Glacial geology and glacial-isostasy, Hudson Bay, Canada. In: Smith, D.E. and Dawson, A.G. (eds.). Shorelines and Isostasy. Academic Press, London, p. 285-319.

Praeg, D.B., MacLean, B., Hardy, I.A. and Mudie, P.J., 1986. Quaternary geology of the southeast Baffin Island continental shelf. Geological Survey of Canada Paper no. 85-14, 38p. (with maps).

Prest, V.K., 1969. Retreat of Wisconsin and Recent ice in North America. Geological Survey of Canada, Series A, Map 1257 A.

Prest, V.K., 1984. The Late Wisconsin glacier complex. In: Fulton, R.J. (ed.), Quaternary Stratigraphy of Canada - A Canadian Contribution to IGCP Project 24. Geological Survey of Canada Paper 84-10, p. 21-38, (Map $1584 \mathrm{~A}$ in pocket).

Ruddiman, W.F. and MeIntyre, A., 1981. The mode and mechanism of the last deglaciation; Oceanic evidence. Quaternary Research, v. 16, no. 2, p. 125-134.

Scott, D.B., Mudie, P.J., Vilks, G. and Younger, D.C., 1984. Latest Pleistocene-Holocene paleoceanographic trends on the continental margin of eastern Canada: Foraminiferal, Dinoflagellate and Pollen evidence. Marine Mieropaleontology, v. 9, no. 3, p. 181-218.

Shilts, W.W., 1985. Geological models for the configuration, history and style of disintegration of the Laurentide Ice Sheet. In: Woldenberg, M.J. (ed.). Models in Geomorphology, Binghamton Symposia in Geomorphology, International Series v. 147. Allen and Unwin, Boston, p. 73-92.

U.S. Department of Energy, 1985. Glaciers, ice sheets, and sea level: Effect of a $\mathrm{CO}_{2}$-induced elimatic change. keport of a workshop held in Seattle, Washington 1984. DOE/ER/60235-1. Washington, D.C., 345p.

Williams, L.D., 1979. An energy-balance model of potential glacierization of northern Canada. Arctic and Alpine Research, v. 11, no. 4, p. 443-456. 